\title{
Transient Bacteremia Caused by Atopobium Vaginae After Caesarean Delivery: Case Report
}

\author{
Slobodanka B. Stefanović ${ }^{1}$, Ljubinka I. Nikolić2 , Snežana D. Jovanović ${ }^{1}$, \\ Emina S. Čolak ${ }^{3}$, Dušan N. Vukolić ${ }^{2}$
}

\author{
${ }^{1}$ Department of Microbiology Clinical Center of Serbia, Belgrade, Serbia \\ ${ }^{2}$ Clinic for Gynecology and Obstetrics, Clinical Center of Serbia, Belgrade, Serbia \\ ${ }^{3}$ Institute of medical Biochemistry, Clinical Center of Serbia, Belgrade, Serbia
}

\section{SUMMARY}

Introduction: Genital microbiome of woman is still a puzzle to this day. It consists of a large number of different bacterial species and phenotypes that make up the normal genital flora, while in the cases of its change there is a predominance of certain, especially anaerobic species, which is the case with bacterial vaginosis. These types are mostly rare causing invasive infections, but under certain conditions can lead to severe infections, such as multiple parts of the genital tract, and to an unwanted outcome in the pregnancy.

Case report: This paper presents an extremely rare case of transient bacteremia caused by Atopobium vaginae type in a patient following a cesarean section where empirical therapy gave a positive effect and the patient recovered and released home with healthy newborn.

Conclusions: During the clinical work it is important to be aware of the different anaerobic species present in the genital tract of women microbiome like Atopobium vaginae and should adjust the empirical therapy, which was the case here.

Keywords: transient bacteremia, Cesarean section, Atopobium vaginae, bacterial vaginosis, empirical therapy

\section{INTRODUCTION}

Cesarean section (SC) as a method of delivery has greatly contributed to the improvement of perinatal outcome. The number of SCs is steadily increasing. The death outcome of women in reporting is today a rarity, and newborns are better fit for post-natal life. On the other hand, $\mathrm{SC}$ as a surgical intervention follows a number of problems, such as an increase in the number of thromboembolic complications and an increased risk of developing infections, septic conditions and bacteremia [1-3].

Bacteremia is defined as the presence of alive bacteria in the bloodstream. Bacteremia could be primary, where bacteria enter the bloodstream directly or secondary by entering in the bloodstream from another body site (wounds, respiratory tract, gastrointestinal tract, bladder, genital tract). By the timing of bacteria presence in the bloodstream, bacteremia can be defined as transient where bacteria 
are present for a minutes to a few hours, intermittent where bacteria is present periodical by existing an infection elsewhere in the body or as persistant. Bacteremia as clinical condition differ from sepsis where bloodstream infection is associated with serious inflammatory response, untreated lead even to the death. Bacteremia in this population is mostly associated with earlier gestational age, lower birth weight, and chorioamnionitis [1-4].

Up today there is no sufficient data about transient bacteremia after SC. The most cases descriebed were sepsis coused by mostly aerobic bacteria and small percent by different anaerobic species.

Only one case of transient bacteremia caused by Atopobium vaginae has been described in the literature so far, and only two cases of sepsis caused by other Atopobium species $[5,6]$.

\section{THE AIM}

The aim of this paper is to point out the occurrence of postpartum transient bacteremia after the SC caused by unexpected, rare bacterial species found in the genital tract of the woman.

\section{CASE REPORT}

A 34 years old woman in $39^{\text {th }}$ week of pregnancy was admitted at the Clinic for gynecology and obstetrics of the Clinical Center of Serbia to be prepared for the delivery. The patient was in a good general condition. The presence of diabetes mellitus in pregnancy (DMG) and thrombophilia, a genetically confirmed mutation for the plasminogen activator inhibitor (PAI 1) 4G / 4G is recorded according to anamnesis and is based on provided documents. During the examination condylomas of the vulva and perineum were detected (Condylomata accuminata vulvae et perinea). The position of the fetus was ad pedem.

Due to the presence of condylomas and ad pedem fetus position it was decided to deliver a baby with SC.

In accordance with the routine procedure before cesarean section samples of cervical and vaginal swabs were obtained, urine, for bacteriological analyzes, blood for blood typing, biochemical analysis, complete blood count, C-reactive protein (CPR), and screening of hemostasis tests. All hematological and biochemical blood tests were within the reference range.

The patient was blood group $\mathrm{A}, \mathrm{RhD}$ positive. Since it was decided perform the delivery via SC, one unit of leukodepleted packed red blood cells was crossmatched.

Pathogenic bacteria were not isolated from genital swabs. On the direct microscopic smear, colored with standard Gram stain a small number of lactobacilli were found, "Clue - cells" free. The bacteriological result of urin sample, in the context of SC preparation, was sterile.

SC was performed in total anesthesia and on that occasion a healthy female newborn in 39 weeks of gestation was born, with birth weight of 3200 grams, a body length of $51 \mathrm{~cm}$, a head circumference of $34 \mathrm{~cm}$ and Apgar score 9 and 10 in the first and fifth minutes respectively.

According to the procedure of the Clinic, the patient received an antibiotic intravenous prophylaxis with cephalosporin of the third generation Azaran ${ }^{\circledast}$ (ceftriaxone, powder for solution for injection / infusion, 1000mg, glass lio-bottle, Hemofarm a. d. Serbia) $2 \mathrm{~g}$ / 24h, and antithrombotic prophylaxis with low molecular weight heparin, Fraxiparine ${ }^{\circledast}$ (nadroparin-calcium, 2850 i.j. / $0.3 \mathrm{~mL}$, solution for injection in a loaded syringe, Aspen Europe GmbH ogranak Beograd) 0.3ml / 12h. After intervention was completed, the infusing therapy of Azaran 2gr / 24h in combination with metronidazole (metronidazole 500 mg / $100 \mathrm{ml}$ infusion solution- glass bottle Alleman Pharma GMBH, Germany) $500 \mathrm{mg} / 8 \mathrm{~h}$ was continued in the obstetric intensive care unit. In addition to antibiotic therapy, symptomatic therapy was also used: Ranisan (ranidtidine, film tablets, $150 \mathrm{mg}$, Zdravlje AD, Serbia) 1 tablet at $12 \mathrm{~h}, \mathrm{Clometol}^{\oplus}$ (Metoclopramide, tablet, $10 \mathrm{mg}$, Galenika a. d. Serbia) 1 tablet as needed, Novalgetol ${ }^{\oplus}$ (metamizolesodium, $2.5 \mathrm{~g} / 5 \mathrm{ml}$, solution for injection of ampoules, Galenika a. d. Serbia) 1 ampoule intramuscularly at $8 \mathrm{~h}$ and Diclofen DUO (diclofenac, capsule, $75 \mathrm{mg}$, Galenika a. d. Serbia) as needed. Laboratory parameters on the same day after S. C. have shown the following values: total leukocytes number was 21. 08x10e9 / L, of which 18.6x10e9 / L were neutrophil granulocytes, in favor of a indicative bacterial infection. The erythrocytes were $3.95 \times 10 \mathrm{e} 12$ / L, hemoglobin $122 \mathrm{~g} / \mathrm{L}$, platelets cells $319 \times 10 \mathrm{e} 9$ / L, CRP less than 5. $6 \mathrm{mg} / \mathrm{L}$, prothrombin 
time (PT) $84 \%$, activated partial thromboplastin time (aPTT) 25. 3 seconds, fibrinogen 4.2 $\mathrm{g} / \mathrm{L}$, glucose $6.0 \mathrm{mmol} / \mathrm{L}$, urea $5.0 \mathrm{mmol} / \mathrm{L}$, creatinine $119 \mathrm{umol} / \mathrm{L}$, proteins $43 \mathrm{~g} / \mathrm{L}$, alanine amino transferase (Alt) $16 \mathrm{U} / \mathrm{L}$, Ast $20 \mathrm{U}$ / L, gamma-GT 7 U / L, lactate dehydrogenase (LDH) $471 \mathrm{U} / \mathrm{L}$ and total bilirubin $1 \mathrm{umol} / \mathrm{L}$ (Table 1).

The bacteriological uterine swab, also performed at the Clinic as a routine procedure at the SC, was sterile.

An antibiotic from the group of aminoglycosides, Amikacin ${ }^{\circledR}$ (amikacin, solution for injection / infusion, $500 \mathrm{mg}$, ampoule, Galenika AD, Serbia), $1 \mathrm{~g} / 24 \mathrm{~h}$ is added two days after the SC in therapy, administered in the same infusion manner by ceftriaxone and metronidazole to act as a triple antibiotic therapy. In addition, antithrombotic prophylaxis and supportive therapy have been continued.

In the post-operative period, the patient is afebrile, the leukocytes are normalized and achieve a value of 10. 20x10e9 / L. However, the CRP value is $191.5 \mathrm{mg} / \mathrm{L}$.

After 6 days of hospital stay, due to elevated CRP values and body temperature, three sets of blood cultures in aerobic and an- aerobic bottles were sampled successively.

Blood cultures were incubated for five days in an automated blood culture system BactAlert apparatus (BioMerieux, France), according to the manufacturer's recommendation and according to the most commonly isolated pathogens typical for this population of patients.

Concerning targeted samples sent for bacteriological analysis, Enterococcus spp. was isolated from the swab of lochia in a small number, the cervical and vaginal swabs culture remained sterile. In a direct microscopic Gram smear the presence of a small number of lactobacilli and a small cocobacillary form of bacteria was found. Staphylococcus spp. coagulase negative was isolated from the wound swab.

Antibiotic therapy has been replaced, cephalosporin ceftriaxone and aminoglycoside amikacin are excluded, carbapenem included, Merocin (meropenem, infusion powder, 500 mg, glass lio-bottle, Pharmaswiss D. ABOUT. O, Swiss) $500 \mathrm{mg} / 8 \mathrm{~h}$, glycopeptide antibiotic Vancomycin-MIP (vancomycin, powder for solution for infusion, $1000 \mathrm{mg}$, glass lyo-bottle Chephasaar Chemisch-Pharmazeutische Fabrik GmbH, Germany) 1gr / 12h and met-
Table 1. Laboratory parameters report immediately after SC

${ }^{1} \mathrm{CBC}$ was performed on the hematologic analyzer Advia 2021i, Siemens Germany

${ }^{2}$ CRP was re-established on the BNProSpec Siemens Symbol, Germany

${ }^{3}$ tests of hemostasis were performed at CS 2000 Siemens Siemens

${ }^{4}$ Biochemical parameters were performed on the biochemical apparatus Cobas Roche France

\begin{tabular}{|c|c|c|}
\hline Parameter & Findings & Reference values \\
\hline Leukocytes (x10e9/L) ${ }^{1}$ & 21.08 & $4.0-10.0$ \\
\hline Neutrophil granulocytes (x10e9/L) ${ }^{1}$ & 18.60 & $2.0-7.5$ \\
\hline Lymphocytes (x10e9/L) ${ }^{1}$ & 1.27 & $0.80-4.50$ \\
\hline Monocytes (x10e9/L) ${ }^{1}$ & 0.70 & $0.16-0.80$ \\
\hline Eosinophil granulocytes $(\times 10 \mathrm{e} 9 / \mathrm{L})^{1}$ & 0.080 & $0.04-0.30$ \\
\hline Basophil granulocytes $(\times 10 \mathrm{e} 9 / \mathrm{L})^{1}$ & 0.040 & $0.00-0.10$ \\
\hline Erythrocytes (x10e12/L) ${ }^{1}$ & 3.95 & $4.00-5.50$ \\
\hline Hemoglobin $(g / L)^{1}$ & 122.0 & $120.0-160.0$ \\
\hline Platelets $(\times 10 \mathrm{e} 9 / \mathrm{L})^{1}$ & 319.0 & $150.0-400.0$ \\
\hline $\mathrm{CRP}(\mathrm{mg} / \mathrm{L})^{2}$ & 5.6 & $<5$ \\
\hline PT $(\%)^{3}$ & 84 & $80-120$ \\
\hline aPTT $(s)^{3}$ & 25.3 & $22-32$ \\
\hline Fibrinogen $(\mathrm{g} / \mathrm{L})^{3}$ & 4.2 & $2.0-4.0$ \\
\hline Glucose $(\mathrm{mmol} / \mathrm{L})^{4}$ & 6.0 & $3.9-6.1$ \\
\hline Urea $(\mathrm{mmol} / \mathrm{L})^{4}$ & 5.0 & $2.5-7.5$ \\
\hline Creatinine (umol/L) ${ }^{4}$ & 119 & $45-84$ \\
\hline Proteins $(g / L)^{4}$ & 43 & $62-81$ \\
\hline Alt $(U / L)^{4}$ & 16 & $<41$ \\
\hline Ast $(U / L)^{4}$ & 20 & $<37$ \\
\hline Gamma-GGT (U/L) ${ }^{4}$ & 7 & $<38$ \\
\hline $\mathrm{LDH}(\mathrm{U} / \mathrm{L})^{4}$ & 471 & $220-460$ \\
\hline Bilirubin (umol/L) ${ }^{4}$ & 4.1 & $<20.5$ \\
\hline
\end{tabular}




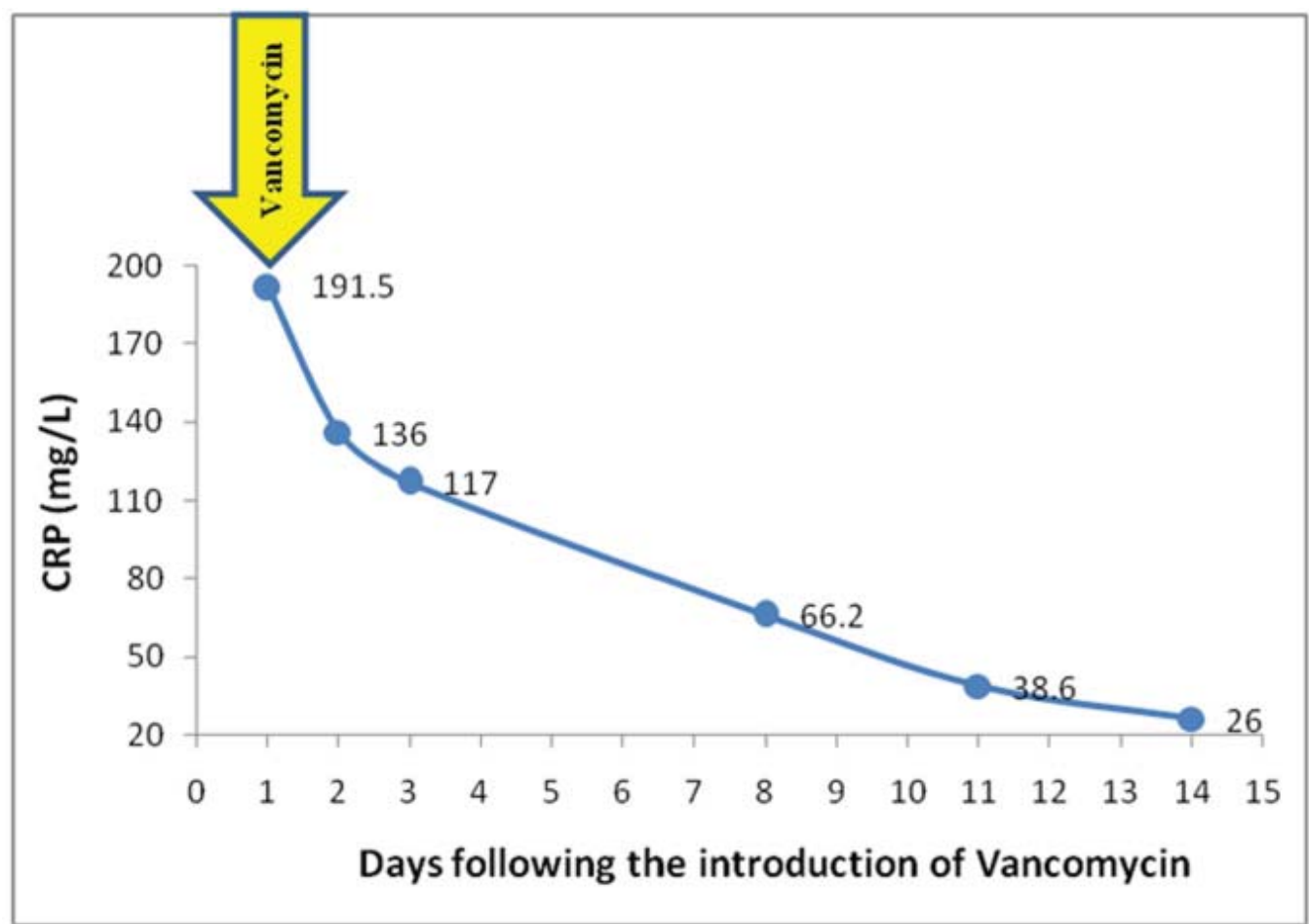

Figure 1. Serum CRP decrease after the introduction of Vancomycin-MIP $\circledast$ therapy

CRP - C-reactive protein

ronidazole in the same previously administered dose. Other therapy administered to patient involved Chymoral forte (trypsin / chymotrypsin combinations, 100,000 Armory units (AI), gastro-resistant tablet, Galenika, a.d. Serbia) $3 \times 2$, Novalgetol ampoule 1 daily as needed and probiotic $2 \times 1$. The dose of Fraxiparin due to a low preventive level (anti-Xa = $0.15 \mathrm{IU} / \mathrm{ml}$ ) was increased to $0.4 \mathrm{ml} / 12 \mathrm{~h}$.

Following two days of administered therapy, from the wound swab was again isolated Staphylococcus spp coagulase negative, while the lochia swab culture remained sterile. The patient remains on the same antibiotic therapy in the following days. After five days under the same antibiotic therapy, the bacterial swabs of the wound and the abdominal puncture remained sterile and the CRP values fell (Fig. 1.).

In the blood culture set, sampled in the second phase of fever, on the fifth day after the start of its incubation, the apparatus detected the presence of bacterial elements in the anaerobic bottle. In a direct microscopic smear colored with standard Gram stain, from the positive anaerobic bottle in which the apparatus detected the growth of the pathogen, the presence of Gram positive coccobacilli was deployed individually, in pairs or shorter chains. Positive anaerobic bottle is sub-cultivated to conventional anaerobic and aerobic media. Media incubated under aerobic conditions remained sterile, while on media incubated under anaerobic conditions after 48 hours the growth of bacterial elements was detected. Gram positive coccobacillus were noticed by standard Gram stain.

Identification of the isolated pathogen to the level of the species was done on the VITEK 2 Compact apparatus. In this case, a bacterial species of Atopobium vaginae was identified with a probability of $90 \%$. However, the device did not determine the antimicrobial sensitivity of the identified pathogen.

The other two sets of blood cultures were negative, without the presence of a pathogen.

\section{DISCUSSION}

Infections caused by bacteria Atopobium vaginae occur rarely and generally occur after gynecological invasive interventions and procedures. They have been described in the case of a tubo-ovarial abscess occurring in the case of transvaginal detection of the oocyte, and it has recently been described in the case of endometriosis [7-9].

Atopobium vaginae was discovered in 1999. Until 2004, these strictly anaerobic 
Gram positive coccobacilli were considered as normal bacterial flora of the women's vagina [10]. The change in the physiological flora of the vagina, dysbiosis, or generally altered normal ecosystem of the vaginal microbiome is characterized by a reduced number of lactobacilli. The most common dysbiosis is bacterial vaginosis that, in addition to the absence of a small number of lactobacilli, is characterized by the presence of a large number of different anaerobic species, some of which are specific for this condition. Today it has been proven that Atopobium vaginae is found in over $90 \%$ of cases in women with bacterial vaginosis and about $80 \%$ in its intermediate phase. Bacterial vaginosis is also often associated with other sexually transmitted pathogens: Mycoplasma hominis, Ureaplasma urealyticum/parvum, Chlamidia trachomatis, rarely with Neisseria gonorrhoeae and other pathogens of viral etiology [11-13].

So far, a small number of studies have been concerned with the composition of the vaginal microbiome during pregnancy and before delivery. Vaginal microbiome is stable in most cases. Qualitative studies based on the analysis of conventional culture have determined several hundred different phenotypes in the composition of vaginal microbials that are constantly or occasionally present [13].

In our patient, according to the "Nugent-score" criteria for the detection of bacterial vaginosis on a direct microscopic examination can indicate the intermediate phase of bacterial vaginosis. Bacterial vaginosis can lead to premature delivery or premature rupture of the fetuses membranes [14]. In addition to the above-mentioned risk factors in pregnancy, this condition is also associated with a higher susceptibility to pathogens belonging to sexually transmissible, which was also the case in our patient having genital condylomas caused by Human papilloma virus (HPV) [12-14]. Condylomas are one of the indications for the SC delivery.

No pathogen was identified that would be significant from genital samples and urine samples sent to bacteriological analysis as a regular medical procedure and from targeted samples in the period of increased markers of the inflammatory reaction. All isolated bacterial species were conditionally pathogenic, and empirical therapy and targeted therapy have been proven to be adequate after the antibiotic sensitivity assessment.
In the second set of blood culture the bacterial species Atopobium vaginae was isolated, strictly anaerobic Gram-positive bacteria requiring longer incubation period for its increase.

Certainly, molecular methods are golden standards for the precise determination of species [7], however, in our case, based on the finding of direct microscopic smear, it can be suspected that a patient had an intermediate stage of bacterial vaginosis in which isolated species was identified on VITEK 2 Compact apparatus and whose presence is found in around $80 \%$ of changed vaginal microbioma [13].

According to the European Committee on Antimicrobial Susceptibility Testing (EUCAST), the susceptibility of anaerobic bacteria to antimicrobial drugs is exclusively determined by the method of determining minimal inhibitory concentration (MIC) [15] VITEK 2 Compact apparatus did not specify the MIC for the identified bacterial species, which happens if the inoculum of the bacteria is not sufficiently dense.

The most commonly used antibiotic in anaerobic bacterial species is metronidazole. According to available literature data, the results of the Atopobium vaginae susceptibility testing on metronidazole are controversial, due to the fact that some types have high MIC values. Although, some authors believe that this bacteria has instrinsic resistance to this antibiotic, but some examiners confirmed the susceptibility of the tested isolates of Atopobium vaginae to metronidazole. However, clindamycin is recommended for successful treatment $[13,14]$.

The susceptibility to different groups of antibiotics with different mechanisms of action must certainly be determined by MIC. In all previous studies the susceptibility of this bacterial species to vancomycin was found, where the MIC is about $1.5 \mu \mathrm{g} / \mathrm{ml}$ and according to the EUCAST standard from the year 2018 it belongs to the susceptibility zone for Gram-positive anaerobic bacilli (S2 $\leq 2 \mu \mathrm{g}$ / $\mathrm{ml} ; \mathrm{R} \geq 2 \mu \mathrm{g}$ / l) not including Clostridium difficile $[15,16]$.

Up to now, one case of Atopobium vaginae isolated from blood culture has been described in the any research paper as a transient bacteremia in a patient who underwent gynecological invasive intervention during pregnancy, transcervical sampling of cho- 
rionic ducts by procedures and prescribed guides, without complications [7]. The case of sepsis caused by other Atopobium species is described in patient with fulminant Fournier's gangrene admitted to the hospital due to a perianal abscess that spontaneously drained for a week [5].

\section{CONCLUSION}

Tgenital microbial flora of women is composed of over 300 different species, and some of them can cause serious infections in certain situations. If the patient during the postpartal period was febrile and with septic symptoms, it is important to be aware of the different anaerobic species present in the genital tract of women microbiome, like Atopobium vaginae, and should adjust the empirical therapy, which was the case here.

\section{REFERENCES}

1. Lurie S. The changing motives of cesarean section: from the ancient world to the twenty-first century. Arch Gynecol Obstet. 2005; 271(4):281-5.

2. Seifert, Harald (2009-05-15)."The Clinical Importance of Microbiological Findings in the Diagnosis and Management of Bloodstream Infections".Clinical Infectious Diseases.48 (Supplement 4): S238S245.doi:10.1086/598188. ISSN 1058-4838. PMID 19374579.

3. Sherris Medical Microbiology, 6e. New York: McGraw-Hill. 2014. pp.Infectious Diseases: Syndromes and Etiologies. ISBN 9780-0-7-181821-6

4. Boggess KA1, Watts DH, Hillier SL, Krohn MA, Benedetti TJ, Eschenbach DA. Bacteremia shortly after placental separation during cesarean delivery. Obstet Gynecol. 1996 May;87(5 Pt 1):779-84.

5. Oyaert M, Cools P, Breyne J, Heyvaert G, Vandewiele A, Vaneechoutte $M$ et al. Sepsis with an Atopobium-like species in a patient with Fournier's gangrene. J Clin Microbiol. 2014; 52(1):364-6.

6. Kramer HM1, Schutte JM, Zwart JJ, Schuitemaker NW, Steegers EA, van Roosmalen J. Maternal mortality and severe morbidity from sepsis in the Netherlands. Acta Obstet Gynecol Scand. 2009;88(6):64753. doi: 10.1080/00016340902926734.

7. Knoester M, Lashley LE, Wessels E, Oepkes D, Kuijper EJ. First report of Atopobium vaginae bacteremia with fetal loss after chorionic villus sampling. J Clin Microbiol. 2011 Apr; 49(4):1684-6.

8. Geissdörfer W, Böhmer C, Pelz K, Schoerner C, Frobenius W, Bogdan C. Tuboovarian abscess caused by Atopobium vaginae following transvaginal oocyte recovery. J Clin Microbiol. 2003; 41(6):2788-90.
9. Yamagishi Y, Mikamo H, Tanaka K, Watanabe K. A case of uterine endometritis caused by Atopobium vaginae. J Infect Chemother. 2011 Feb; 17(1):11921.

10. Rodriguez Jovita $M$, Collins MD, Sjödén B, Falsen E. Characterization of a novel Atopobium isolate from the human vagina: description of Atopobium vaginae spp. nov. Int J Syst Bacteriol. 1999; 49(4):1573-6.

11. Fredricks DN, Fiedler LT, Marrazzo MJ. Molecular identification of bacteria associated with bacterial vaginosis. N Engl J Med. 2005; 353(18):1899-911.

12. Datzu R. Characterization of the vaginal microflora in health and disease. 2014. Dan Med J. 61(4):B4830.

13. Shipitsyna E, Roos A, Datcu R, Hallén A, Fredlund $\mathrm{H}$, Jensen $\mathrm{SJ}$ et al. Composition of the vaginal microbiota in women of reproductive age - sensitive and specific molecular diagnosis of bacterial vaginosis is possible? 2013. PLoS One v. 8(4); e60670.

14. Donders GG ,Van Calsteren K, Bellen G, Reybrouck $R$, Van den Bosch T, Riphagen I, Van Lierde S. Predictive value for preterm birth of abnormal vaginal flora, bacterial vaginosis and aerobic vaginitis during the first trimester of pregnancy, 2009;BJOG. 116: 1315-1324.

15. European committee on antimicrobial susceptibility testing - EUCAST 2018. Dostupno na: http:// www.eucast.org/

16. De Backer E, Verhelst R, Verstraelen H, Claeys $G$, Verschraegen $G$, Temmerman $M$ et al. Antibiotic susceptibility of Atopobium vaginae. BMC Infect Dis. 2006; 6:51. 


\section{Tranzitorna bakterijemija prouzrokovana Atopobium-om vaginae nakon Carskog reza: prikaz slučaja}

Slobodanka B. Stefanović ${ }^{1}$, Ljubinka I. Nikolić ${ }^{2}$, Snežana D. Jovanović1, Emina S. Čolak ${ }^{3}$, Dušan N. Vukolić ${ }^{2}$

${ }^{1}$ Služba za mikrobiologiju, Klinički centar Srbije, Beograd, Srbija

${ }^{2}$ Klinika za ginekologiju i akušerstvo, Klinički centar Srbije, Beograd, Srbija

${ }^{3}$ Centar za medicinsku biohemiju, Klinički centar Srbije, Beograd, Srbija

\section{KRATAK SADRŽAJ}

Uvod: Genitalni mikrobiom žene je i do danas zagonetka. Sastoji se od velikog broja različitih bakterijskih vrsta i fenotipova koji čine normalnu genitalnu floru, dok u slučajevima njene promene dolazi do predominacije određenih, posebno anaerobnih vrsta, što je slučaj kod bakterijske vaginoze. Ove vrste su uglavnom retki izazivači invanzivnih infekcija, ali pod određenim uslovima mogu dovesti do težih infekcija, kako viših delova genitalnih puteva, tako i do neželjenog ishoda u trudnoći.

Prikaz slučaja: U ovom radu je prikazan izuzetno redak slučaj tranzitorne bakterijemije izazvane vrstom Atopobium vaginae kod pacijentkinje posle carskog reza gde je empirijska terapija dala pozitivan učinak i pacijentkinja oporavljena otpuštena kući sa svojim zdravim novorođenčetom.

Zaključak: Tokom kliničkog rada treba misliti na različite anaerobne vrste, kao što je Atopobium vaginae, koji su prisutni u mikrobiomu genitalnih puteva žena i prilagoditi empirijsku terapiju, što je ovde bio slučaj.

Ključne reči: tranzitorna bakterijemija, Carski rez, Atopobium vaginae, bakterijska vaginoza, empririjska terapija 